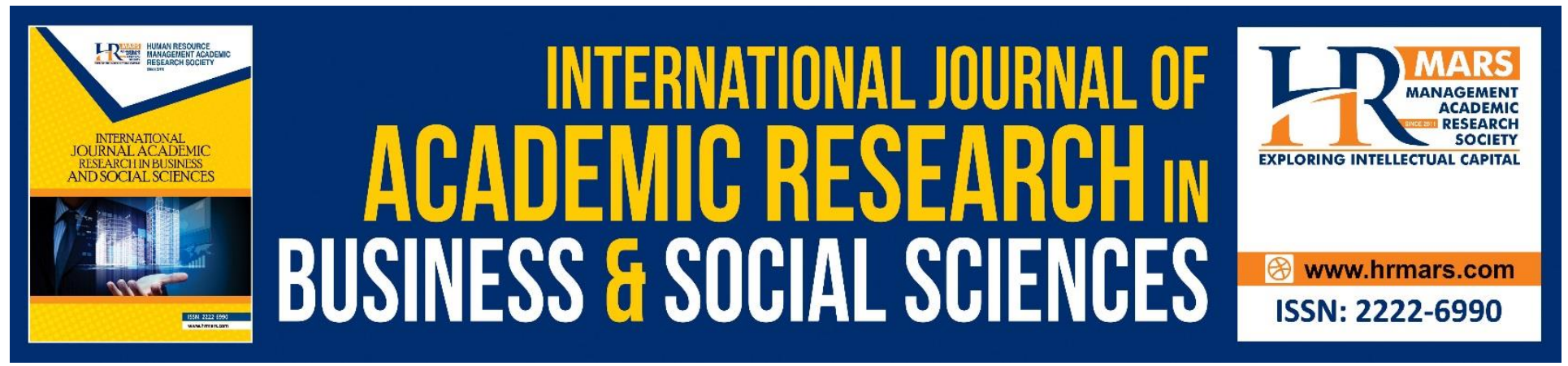

\title{
Entrepreneurship and Small Business Management: Critical Success Factors of Entrepreneurs and Small Business Managers
}

Francis Takwi, Benz Enow Bate, Vivian Neba Akosso, Bejanga Sharon

To Link this Article: http://dx.doi.org/10.6007/IJARBSS/v10-i10/7650

DOI:10.6007/IJARBSS/v10-i10/7650

Received: 24 August 2020, Revised: 18 September 2020, Accepted: 10 October 2020

Published Online: 24 October 2020

In-Text Citation: (Takwi, Bate, Akosso, \& Sharon, 2020)

To Cite this Article: Takwi, F., Bate, B. E., Akosso, V. N., \& Sharon, B. (2020). Entrepreneurship and Small Business Management: Critical Success Factors of Entrepreneurs and Small Business Managers International Journal of Academic Research in Business and Social Sciences. 10(10), 488-503.

Copyright: (c) 2020 The Author(s)

Published by Human Resource Management Academic Research Society (www.hrmars.com)

This article is published under the Creative Commons Attribution (CC BY 4.0) license. Anyone may reproduce, distribute, translate and create derivative works of this article (for both commercial and non-commercial purposes), subject to full attribution to the original publication and authors. The full terms of this license may be seen at: $\underline{\text { http://creativecommons.org/licences/by/4.0/legalcode }}$

Vol. 10, No. 10, 2020, Pg. 488 - 503

http://hrmars.com/index.php/pages/detail/IJARBSS

JOURNAL HOMEPAGE

Full Terms \& Conditions of access and use can be found at http://hrmars.com/index.php/pages/detail/publication-ethics 


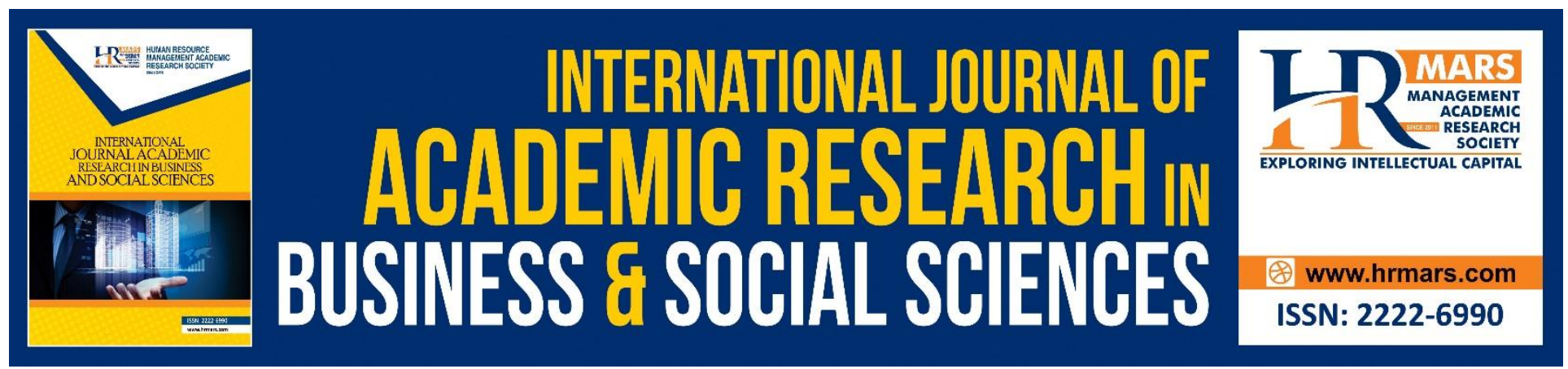

\section{Entrepreneurship and Small Business Management: Critical Success Factors of Entrepreneurs and Small Business Managers}

\section{Francis Takwi, PhD, Benz Enow Bate, PhD, Vivian Neba Akosso, Bejanga Sharon}

Faculty of Business Management and Sustainability, Information and Communication Technology

University usa, Yaounde, Cameroon

Email: francis.takwi@ictuniversity.org, benz.bate@ictuniversity.org, benzcaminternational@yahoo.com,Vivian.akosso@ictuniversity.org, bejanga_sharon@yahoo.com

\section{Abstract \\ Purpose}

The contribution of Entrepreneurs and owner managers in the creation of wealth and employment and overall economic growth is immense. Who is an Entrepreneur, what makes Entrepreneurs successful and what are the factors that contribute to the growth of Small businesses are the main aims of this study. It is also helps to give a clearer understanding of the antecedent, social, economic and demographic factors that influence success of start-ups in Bamenda, as perceived by local Entrepreneurs.

\section{Design}

The initial research framework, which emanated from a systematic literature review, was empirically investigated using a two-stage design, which incorporated both quantitative and qualitative approaches. The rationale behind the two-stage methodology was firstly to avoid common-method bias; and, secondly, to seek to illuminate findings arising from the survey by providing individual insights. Approaches were employed in succession with the findings from the quantitative phase informing the qualitative phase. Initially, a paper and online survey questionnaire was administered to a population of Small businesses. This survey was used in order to validate the initial conceptual framework and gain some insights on the perceptions of Entrepreneurs of the factors influencing the performance of Small businesses. Following the quantitative phase, fifteen in-depth face-to-face semi-structured interviews were conducted with selected creators of startups, forming a judgmental sample, to explore their knowledge, experiences, beliefs, and attitudes with respect to the drivers of success. 
INTERNATIONAL JOURNAL OF ACADEMIC RESEARCH IN BUSINESS AND SOCIAL SCIENCES Vol. 10, No. 10, 2020, E-ISSN: 2222-6990 @ 2020 HRMARS

\section{Findings \& Conclusions}

Three main factors wer4e considered that can lead to the success or failure of Entrepreneurs. These were Antecedent factors particular to the Entrepreneur, personal characteristic of the entrepreneur and Socio-Demographic Characteristics of the entrepreneur. The quantitative phase of the study found that age, education, experience, family background, need for achievement, risk-taking propensity, managerial competences, and functional competences of the Entrepreneur were significantly related to business success. These factors can be grouped under the category of 'Entrepreneurial attributes'. Findings of the two phases of the study showed that a host of internal as well as external factors, which are usually moderated by other variables, seem to influence business success in Bamenda. These findings added substantially to the understanding of Entrepreneurs' views of the factors that contribute to business success in the context of Bamenda, Cameroon.

Keywords: Entrepreneur, Small Business Growth, Entrepreneurship, Business Success.

\section{Introduction}

\section{Study Background}

The important contribution of a vibrant Small businesses sector in the national economic and social development of a country has been widely recognized. In view of its increasing importance, the success of Micro Enterprises (has been of interest to researchers, international organizations, and policy makers, at least since the Bolton report (1971), and therefore has become the subject of a great deal of analysis. Attention to the Small business sector has heightened because of the globalizing economy and the increasingly severe competition that is inherent in this development.

In the light of this, the following research study seeks to understand and explore the factors that influence the success of Entrepreneurs in the city of Bamenda in Cameroon.

The importance of Small businesses is well recognized in academic and policy literature (Storey, 2014). Both developed and developing countries have realized the importance of Small businesses in economic and social development. In Europe, the annual report of European Small businesses confirmed that Small businesses remain the European Union's economic backbone despite the global financial crisis (The European Commission, 2007). Representing 99.8 per cent of all enterprises, Small businesses contribute to 66 per cent of employment in the European Union.

Small businesses in Cameroon play a pivotal role in the development of the country. The importance of Small businesses is evidenced by their high presence in the economic structure of the country. According to The United Nations Economic Commission for Africa (UNECA) (2008), 90\% of all Cameroonian firms are Small businesses and account for $40 \%$ of production, $42 \%$ of investment, $35 \%$ of exports and $50 \%$ of all jobs.

Through the conclusion of a series of free trade agreements with its main trading partners (European Union), Cameroon has embarked in a global economy characterized by fierce competition. This has left no choice for Small businesses but to adapt to the hostile environment and engage in the process of identifying strategies to ensure their business success. Given this situation and being aware of the socio-economic importance of Small businesses, the Cameroonian government has been taking necessary measures and actions to promote the sector and ensure its success. In this regard, the government has deployed the Emergence Covenant that aims to develop a very competitive Small business sector. 
INTERNATIONAL JOURNAL OF ACADEMIC RESEARCH IN BUSINESS AND SOCIAL SCIENCES Vol. 10, No. 10, 2020, E-ISSN: 2222-6990 @ 2020 HRMARS

\section{Statement of the Problem}

Although Bamenda has a very strategic location compared to other cities in Cameroon, the report revealed that Bamenda was the most difficult area in the ease of doing business. This left the author with a profound feeling of anxiety about the success factors of Entrepreneurs and owner managers in Bamenda. What made Small businesses to grow and flourish in this hostile environment was the main motivation behind this study.

The performance of Small Businesses has been of interest to many researchers, international organizations, and policy makers, at least, since the Bolton report (1971), and therefore has become the subject of a great deal of analysis. This performance may have two strategic outcomes that are often referred to in the literature as firm success or failure. In a management field, success and failure can be interpreted as measures of good or indifferent management, but it may occur for other reasons such as luck (Storey, 2005).

Numerous terms have been used in the literature to describe firm failure, for example: bankruptcy, insolvency, liquidation, death, deregistering, discontinuance, ceasing to trade, closure, and exit. These terms overlap each other to some extent and thus, the concept of failure is ambiguous, as it can have different interpretations by different people (Wickham, 2001). The many different interpretations and definitions of both success and failure make it very hard to compare research findings on the performance of small firms.

Very often, the terms 'success', 'survival', 'growth' are very closely linked and sometimes used interchangeably. Besides the multi-dimensional aspect of success, variables that contribute to the success of Entrepreneurs are not unanimously agreed upon by researchers. While some analysts suggested that the dynamics of the success of businesses remain a black box, others argued that the success of enterprises is a function of both external and internal factors ( Markman \& Baron, 2003).

Literature on the performance of Small Businesses usually identifies several causal factors with regard to the internal and external environment of the firm. In terms of internal factors, several researchers have attempted to investigate the antecedent factors that personally influence the Entrepreneur and the external and internal factors that influence Small Businesses performance (Storey, 2005). For the firm characteristics, several studies have revealed that size, age, and location of the firm could be related to business performance. On the other hand, other researchers have shown great interest in understanding the relationship between traits of the Entrepreneur and business performance (Rogerson, 2001).

As for the external factors, it is widely recognized that successful organizations are those that best adapt to fit the opportunities and the constraints inherent in the environment in which they operate, the external environment of the enterprise can be classified into two dimensions, namely the general and competitive environments.

On the other hand, a large and growing body of literature has investigated the competitive environment of the firm in relation to three stakeholders: customers, suppliers, and competitors. There is a large volume of published studies describing the role of customer relationship management as a key factor in business performance. Similarly, an increasing amount of literature has highlighted the effect of suppliers on the performance of businesses. Other researchers have argued that an analysis of the role of competitors and counter-competition intelligence and actions are crucial for the survival of a Microenterprise (Nieman, 2006).

Entrepreneurs are driven to achieve success by several motivators. A driving force for most owner managers to succeed in business was poverty. There is also a strong desire to provide a better life for 
INTERNATIONAL JOURNAL OF ACADEMIC RESEARCH IN BUSINESS AND SOCIAL SCIENCES Vol. 10, No. 10, 2020, E-ISSN: 2222-6990 @ 2020 HRMARS

their children, which is the result of the Entrepreneur's own economically deprived childhood. They have a determination to succeed and have control of their life. They achieve self-determination by economic independence. The need to network and interact with non-indigenes of Bamenda is therefore essential for thefr business success. The intrinsic motivator for Entrepreneurs is to provide for their family, to give their children a better life than what they experienced, and to escape the entrapments of poverty. Discrimination combined with lack of capital and access to micro-credit was seen as the major inhibitors to business success. These broad ranging topics were seen to be of related interest and in the spirit of the smdy, deemed to require further discussion.

As argued by Man \& Lau (2005), Small businesses are more likely than larger firms to be affected by changes in their internal and external environment. Thus, an important issue arises concerning the ability of small and medium firms to cope in a very challenging environment. In attempt to address this issue, the present study has been undertaken with the aim of developing a clearer understanding of the factors that influence success of Small businesses in Bamenda, as perceived by local Entrepreneurs.

\section{Research Objectives \& Questions Research Objectives}

The overall aim of this research is to develop a clearer understanding of the factors that influence success of Small Businesses in Bamenda, as perceived by local Entrepreneurs. In order to achieve this overall research aim, three key objectives are set:

$>$ To identify the salient factors for business 'success' in the opinion of Entrepreneurs in the city of Bamenda;

$>$ To examine differences between owner-managers of 'successful' and 'less successful' Small businesses in relation to the identified salient factors; and

$>$ To explore the experiences of Entrepreneurs of the perceived factors contributing to business success.

\section{Research Questions}

The aim of this research is to answer the following questions about the business and personal success of Entrepreneurs in Bamenda in respect to the theoretical framework identified from the literature review:

$>$ What are the salient factors for business 'success' in the opinion of Entrepreneurs in the city of Bamenda?

$>$ What are the individual, environmental and socioeconomic factors that can lead to business success?

$>$ How do Small businesses Entrepreneurs in Bamenda see these factors for business 'success' in relation to their social environment in the city of Bamenda?

\section{The Rationale of the Study}

The prime motive for conducting this study is to get a comprehensive model relating to the various success factors for Entrepreneurs. Although there have been a number of studies located in Cameroon, these have focused solely on a narrow range of financial success measures. None of these prior studies adopted a systematic review process and the majority of them lie in the grey literature. Arguably, this limits their value and explains their limited research approaches. The need for this 
present study seems therefore self-evident. Based on a systematic literature review, the study addresses this knowledge gap by developing a comprehensive model of various success factors in the context of Bamenda, using both financial and non-financial measures of performance. It is the first study to be conducted in such context.

Bamenda is unequivocally a cosmopolitan city, rich in historical and multi-cultural background. The choice of Bamenda in rests firstly on its strategic location, secondly on the recent and increasing investment in the city and thirdly its role as the third most important business city in Cameroon.

The present study is expected to make a number of contributions in a number of ways. From a theoretical perspective, the study adds new knowledge and extends the growing body of literature in the field of Entrepreneurial Business Innovation. The study has the potential to contribute to the understanding of the critical success factors for Entrepreneurs in the city of Bamenda. It is designed to give rise to a situational model, based on the Bamenda Entrepreneurs' perceptions, that enriches current research by offering new insights with rich information on the factors that tend to be perceived as associated with business success, which has not been done before in this geographical context. From a practical perspective, understanding business success through the different perceived factors covered in this present study is very important. This study could provide Entrepreneurs of Small businesses with knowledge and guidance about the way they could manage and run their businesses in a very successful manner.

\section{Research Methodology}

\section{Research Questions and Objectives Revisited}

This research study sought to explore issues surrounding the successful performance of Small businesses in Bamenda from the perspective of local Entrepreneurs, informed by the theoretical framework identified from the literature review. The questions that guided and focused the study were as follows:

$>$ What are the salient factors for business 'success' in the opinion of Entrepreneurs in the city of Bamenda?

$>$ With reference to the identified salient success factors, what differences, if any, exist between the 'successful' and 'less successful' Small businesses?

$>$ How do Entrepreneurs in Bamenda see these factors for business 'success' in relation to their social environment in the city of Bamenda?

The overall aim of this research was to develop a clearer understanding of the factors that influence success of Micro Enterprises in Bamenda, as perceived by local Entrepreneurs. To achieve the research aim, three key objectives were set out:

$>$ To identify the salient factors for business 'success' in the opinion of Entrepreneurs in the city of Bamenda;

$>$ To examine differences between owner-managers of 'successful' and 'less successful' Small businesses in relation to the identified salient factors; and

$>$ To explore the experiences of start-up managers of the perceived factors contributing to business success. 
INTERNATIONAL JOURNAL OF ACADEMIC RESEARCH IN BUSINESS AND SOCIAL SCIENCES Vol. 10, No. 10, 2020, E-ISSN: 2222-6990 @ 2020 HRMARS

\section{The Research Approach}

The post-positivist philosophy adopted in this research study stresses the use of multiple methods, which might include quantitative and qualitative techniques. Moreover, in descriptive research, the techniques most often used to collect, analyse and summarize data are quantitative techniques, whereas an exploratory study often uses qualitative techniques. Therefore, a mixed methods approach, incorporating both quantitative and qualitative data, is deemed to be appropriate to carry out this study in order to improve the quality of the research. It should be clarified here that the research used a sequential mixed-methods strategy whose logic became emergent during the course of the research - in other words, he mixed-methods approach developed as the research went along. The study initially followed the tradition used in Business management research, which has historically been primarily positivist in its paradigmatic stance, using purely quantitative approaches. Although there has been some movement away from purely quantitative approaches, attention to qualitative methods has generally been limited. Although results found from the adoption of the quantitative approach were important, they were however inconclusive since constructs used in the survey, derived from the literature, were imposed on respondents. This did not allow an enough understanding of participants' personal view of the salient factors that influence business success. Due to the inconclusive nature of the quantitative survey, it was decided to conduct further research using a qualitative strategy. The quantitative research, however, was vital in order to provide a spring board for the qualitative phase. It aimed to profile respondents according to financial and non financial criteria (e.g. turnover, personal satisfaction) and provided the selection of interviewees that would be able to respond to the issues that were explored further. The reason for the second phase is then derived from the need to illuminate the quantitative findings and potentially enhance our understanding of the salient factors of success in Bamenda. Thus, the combination of a mixed methods approach is used in order to provide richer in-depth understanding and insights into participants' perspectives of Entrepreneurial success. Furthermore, the mixed methods approach is used to avoid common method bias that could affect the results of this research study. Having critically reviewed the literature systematically and built the theoretical framework, a quantitative approach, using deductive reasoning, was utilised in order to gather appropriate data, test the theoretical framework and gain general understanding of the factors that influence the success of Entrepreneurs in Bamenda. Following that, a qualitative approach, using inductive reasoning was adopted. The qualitative approach was carried out at this second stage in order to gain an in-depth understanding over the generalized data and to enable the building of the final situational model related to the success of Entrepreneurs in Bamenda.

\section{Sampling Procedure and Data Collection \\ Population}

To carry out a census, the population of interest has to be clearly and accurately defined. Burns (2004) defined a population as all elements (individuals, objects and events) that meet the sample criteria for inclusion in a study. According to Polit \& Hungler (1999), a population is the totality of all subjects that conform to a set of specifications, comprising the entire group of persons that is of interest to the researcher and to whom the research results can be generalized. In order to define the population of this study, several steps were required to come up with the list of Entrepreneurs to be studied. The first step was to decide on the Small businesses definition that will be used to define the 
population. There is no universally agreed definition of Small businesses. The definition varies from country to country depending on the size of the economy. In Cameroon, several definitions exist. However, the official definition was used based on the number of employees. The latter was chosen in accordance with the argument of Child (2003) who argued that employment is an adequate criterion for the measurement of the size of an organisation, because it is above all human beings who are 'organized'. Therefore, this research study considered enterprises with a headcount between 1 and 10 employees as Small businesses. Having decided on the definition to be used for Small businesses to define the population in Bamenda, the second step consisted of the selection of an official and reliable source of information to identify the Small businesses. All Small businesses operating in Bamenda Cameroon were identified. However, the generated Small businesses list was dated 2007, which is quite old. In order to include up-to-date information about Small businesses, other up-to-date sources of information were needed. Small businesses were cross-checked. The cross checking task resulted in deleting four enterprises from the identified initial list since they had more than 100 employees. Having completed all these steps, a final list of up to date Small businesses, comprising 200 enterprises, was created.

In the light of this, it should be noted here that the population identified by researcher was less than 500 Small businesses in Bamenda.

\section{Questionnaire Distribution and Collection}

Following the refinement of the questionnaire, data collection was carried out. The questionnaire was distributed to the business Entrepreneurs of the selected firms. The distribution of the questionnaire was done in two phases: The 'drop and collect' phase and the online phase.

\section{Drop and Collect Phase}

This phase took place in November 2018. Companies were approached in person. The purpose of the study was explained to them, and they were briefed about the ethical considerations and then were asked to fill in the questionnaire. It should be noted here that network connections were used in order to ease the access to these enterprises. Some Entrepreneurs did fill in the questionnaire on the spot, whereas, some others requested their collection at a later time. A time frame of one week was agreed in order to allow these Entrepreneurs to fill in the questionnaire at their convenience. The process was completed in three weeks, precipitating a total of 97 collected questionnaires.

\section{The Online Phase}

The questionnaire was also administered online. This phase took place in December 2018 and January 2019. Emails were sent to the distribution list, created in a mail box 'feedback Cameroon', which contained the list of Small businesses with email addresses identified.

A number of steps were incorporated in this phase. In the first step, an email giving an overview about the study and its purpose was sent on the 10th December 2018 to 100 enterprises. The email invited the Entrepreneurs of the enterprises to fill in the online English questionnaire following the link that was clearly included in the email. The online questionnaire was designed in such a way that respondents could stop in the middle of the survey, if they wished, by using the 'postpone' and 'resume later' buttons. This function was to allow respondents to complete the questionnaire at their own convenience. The deadline was set for 15th December 2018. Only two enterprise filled in the English questionnaire and did provide its name and address in order to get the results of the study. 
Having received only five responses, a move to the second step was then required. A first reminder was sent to the enterprises, excluding the enterprise that replied to the first email and the enterprises whose emails bounced. The reminder addressed again the purpose of the study and explained that a French version of the questionnaire has also been developed besides the English version. The Entrepreneurs of Small businesses were then invited to fill in the questionnaire in the language they feel most comfortable with. The deadline was set for 20th December 2018.

Following the low number of responses, a decision to move to the third step was taken by sending a second courtesy reminder. The reminder explained that few responses had been received but that, to get more accurate and robust results, the research still needed more participants to share their views about the study. Therefore, the reminder provided an extension of deadline to the participants. The deadline was set for 24th December 2018. This step triggered only two responses. The low number of responses could be explained by the fact that December is a month in which enterprises undertake their inventory audits and thus they were busy and did not have time to fill in the questionnaires.

In total, 104 questionnaires were returned: 97 in the initial 'drop and collect' phase and 7 after prompting. This was an overall response rate of $30 \%$. Of the 104 questionnaires received, 4 were discarded as incomplete, meaning that 100 fully completed questionnaires were returned, providing a net response rate of $35 \%$.

It should be made clear that this study is not unusual in terms of difficulty experienced in obtaining responses from Entrepreneurs, as other researchers have reported similar problems. Reid et al. (1999) suggest that a major difficulty in any research that involves surveying small businesses is achieving an adequate response rate, with many studies reporting rates as low as $10 \%$.

\section{Interview Administration}

The data collection for the qualitative phase took place from October 2018 to December 2018. It was carried out in two separate time frames due to logistical and practicable reasons. Arrangements were made to meet up with Entrepreneurs in November 2007 to carry out more interviews. As a result, another ten interviews were conducted within this month totalling to a number of fifteen interviews. The break between the two interview periods did provide time to reflect on the preliminary analysis of the interviews. All interviews were individual, face-to face interviews and were conducted using the english language. The duration of the interviews ranged from 30 to 60 minutes. With regard to the settings, the strategy was to allow all informants to choose the location so as they could feel more relaxed. The strategy resulted in nine interviews being conducted at the participants' business premises, five in a coffee shop, and one while driving a car.

Prior to undertaking each interview, a verbal brief about the aim of the study and issues related to confidentially was given to participants. The permission to audio record the interview by a digital recorder was sought from the interviewee. Permission was granted and all the fifteen interviews were audio recorded. Furthermore, ownership and copyright of transcripts were established at this stage and participants were informed that transcripts will be destroyed once the research study has come to an end.

During the interview, an open-ended flexible approach to interviewing, was used. Thus, open-ended questions were deliberately asked to encourage participants to engage in the conversation. The flexible approach was useful and did result in new emerging issues to be explored. Furthermore, participants' responses were frequently rephrased and repeated in order to ensure accurate 
understanding of the main points and encourage the interviewees to expound their views on these points.

At the end of the interview, a standard form was given to participants to fill in their personal characteristics such as: age, gender, and educational background, as well as the firm characteristics such as: legal status, activity of the enterprise, years in business, and number of employees. Moreover, participants were reassured again about the confidentiality issues and were alerted that they could be contacted should the researcher need more clarification.

Before conducting the interview, time and location should be agreed with the participants. The interview schedule and location was established at the convenience of the participants. At the start of each interview, participants were reassured that all information will be kept confidential and that their anonymity will be respected. Furthermore, participants were asked whether they have any objection to the use of audio recorder during the interview. The interviewer then explained the nature and aim of the research. During the interview process, notes were taken in addition to the audio recording, in case of any technical failure with the equipment used. At the end of the interview, the participant was thanked for taking part and reassured again that confidentiality and anonymity will be respected.

\section{Data Analysis}

Quantitative data refers to numerical and standardized data, which usually can be analysed through using of diagrams and statistics. In this research study, the process of analysing quantitative data included: data preparation, descriptive analysis, inferential analysis, and content analysis. In order to analyse the data, the software Microsoft Excel with add-ons was used. The reason for this is that the software allows the discovery of differences and relationships in data. As mentioned previously in section the developmental phase, the levels of measurement were not considered in this study.

\section{Discussion of Findings}

At the outset, it was stated that the overall aim of this research study was to develop a clearer understanding of the factors that influence success of Micro Enterprises in Bamenda, as perceived by local Entrepreneurs. To achieve this aim, the study utilized a "mixed-method" approach. In the first phase, a quantitative approach was employed in the form of a survey questionnaire, in order to identify the critical success factors for Small businesses in the city of Bamenda as perceived by Entrepreneurs and to classify and compare successful and less successful Small businesses with respect to the identified factors. The second phase adopted a qualitative approach to explore how Entrepreneurs see the factors that facilitate business 'success' in relation to their experiences in Bamenda.

\section{Socio-Demographic Characteristics Age of the Entrepreneur}

Findings of the quantitative phase revealed a significant association between the age of the Entrepreneur and business success. Descriptive statistics indicated that the majority of successful Entrepreneurs were between the age of 25 and 45. Moreover, results of the inferential analysis, showed significant differences between successful and less successful Small businesses in Bamenda, in relation to the age of the Entrepreneur. Findings suggested that the Entrepreneurs in the younger age category were more likely to be Entrepreneurs of successful businesses. Not surprisingly, the 
findings reflect the age structure of the Cameroonian population that is characterised by the predominance of youth.

The finding of the present study would appear to be at odds with the research of Koffi (2006) who found that among the failure factors of Small businesses in Cameroon is the relatively young age of the Entrepreneurs ( $<35$ years). It also contradicts the findings of Woldie et al. (2008) who undertook an exploratory study of Entrepreneur and firm characteristics to identify the factors affecting the growth of Small businesses in Nigeria. Specifically, using a survey self-administered questionnaire on a sample of 523 Entrepreneurs, their study reported that middle-age and older Entrepreneurs tend to run more growth oriented firms. However, it is consistent with those undertaken in different contexts, such as the study of Reynolds et al. (2000) who found that individuals aged 25-44 years were the most Entrepreneurially active. A possible explanation of the findings from this study is that while some of the younger Entrepreneurs in Bamenda do indeed make serious mistakes and fail, those that survive tend to manage with a stronger growth orientation.

\section{Gender}

In the quantitative phase of the study, the gender variable was found to have no significant association with business success. Descriptive statistics indicated that the majority of Agribusiness firms were owned or managed by men. In fact, only ten of the respondents were female; and this did not allow for statistical analysis. This could be explained by different factors related to the social structure of Cameroon. In addition, results of the inferential analysis, showed no significant differences between successful and less successful Small businesses in Bamenda, in relation to the gender of the Entrepreneur. An explanation is that given a sample within which the vast majority of respondents are of the same gender, a valid comparison between genders is impossible.

\section{Antecedent Factors}

\section{Education}

The quantitative data analysis revealed that education of the Entrepreneur seems to have a paramount importance in ensuring the success of Entrepreneurs in Bamenda. Descriptive statistics revealed that the proportion of Entrepreneurs who have attained high levels of education is higher in successful firms compared to their counterparts in less successful firms. Additionally, results of the inferential analysis, using the Mann-Whitney $U$ test, revealed significant differences between successful and less successful Small businesses in Bamenda, in relation to the education of the Entrepreneur. Findings of both descriptive and inferential statistics suggested that Entrepreneurs of successful firms are characterised with relatively higher levels of education than their counterparts in less successful Small businesses in Bamenda. This suggests that there is a strong link between the education of the Entrepreneur and success of the firms. The finding shows similarities to previous studies conducted in Cameroon. Specifically, the finding supports the study of Gray (2006) who found that education of the Entrepreneurs was helpful for the success of their firms. Furthermore, it seems to be consistent with the study of Koffi (2006), who showed that the poor education of Entrepreneurs represented a factor for the failure of firms in Ghana. Education of Entrepreneurs is important for the success of their businesses. Unfortunately, the Cameroonian education system does not help towards business success. 
INTERNATIONAL JOURNAL OF ACADEMIC RESEARCH IN BUSINESS AND SOCIAL SCIENCES Vol. 10, No. 10, 2020, E-ISSN: 2222-6990 @ 2020 HRMARS

\section{Previous Experience}

In the quantitative phase of the study, previous work experience was considered to have a great impact on the success of Entrepreneurs in Bamenda. Descriptive statistics indicated that Entrepreneurs of both successful and less successful Small businesses tend to have a reasonable number of years of work experience. However, the relevance of the work experience to the business was more highly correlated for the successful firms than their less successful counterparts. Results of the inferential analysis, corroborate the findings of the descriptive analysis and further revealed interesting findings with respect to the previous experience factor. Contrary to expectations, the study did not find significant differences between Entrepreneurs of successful and less successful Small businesses in Bamenda, in relation to the number of years of work experience. However, significant differences were found between the two groups in relation to the relevance of experience to the business. The finding supports the study of Koffi (2006) who found that poor professional experience was a strong failure factor for Small businesses in Cameroon.

\section{Family Background}

The quantitative phase unveiled important findings about the family background factor. Data analysis indicated that family background tends to influence the success of Entrepreneurs in Bamenda. Descriptive statistics showed that Entrepreneurs of successful firms have relatively more educated parents than Entrepreneurs of less successful firms. This result, shown in the descriptive analysis, seems to corroborate the study of Gray et al. (2006) about motivations of Cameroonians to be Entrepreneurs. Specifically, Gray et al. (2006) found that half of the interviewed Cameroonian Entrepreneurs came from families where the father or mother, considered as their role model, was self-employed. In addition, The inferential analysis, using the Mann-Whitney $U$ test, further supports the results of descriptive statistics by illustrating significant differences between the Entrepreneurs of less successful and successful Small businesses in Bamenda, in relation to family background.

\section{Personality Characteristics Need for achievement}

From the quantitative phase, the variable need for achievement was found to have positive impact on the success of Entrepreneurs in Bamenda. Descriptive statistics identified the need of achievement as a common trait for Entrepreneurs of both successful and less successful Small businesses in Bamenda. This result conforms to the findings of Gray et al. (2006) who found that high need for achievement was identified as a common trait for Cameroonian Entrepreneurs. However, interestingly, significant differences were found between the two groups. Results of the inferential analysis, revealed that the need for achievement was higher for Entrepreneurs of successful firms than for their less successful counterparts.

\section{Locus of Control}

In the quantitative phase of the study, the variable locus of control was found to have no significant association with business success. It was apparent from the descriptive statistics that Entrepreneurs of both successful and less successful firms expressed a neutral opinion in relation to locus of control. In addition, the results obtained from the inferential analysis, using showed no significant differences between the two groups. Respondents believed in working hard to achieve success but that destiny plays a major role in determining such success. A plausible explanation for this result could be related 
INTERNATIONAL JOURNAL OF ACADEMIC RESEARCH IN BUSINESS AND SOCIAL SCIENCES Vol. 10, No. 10, 2020, E-ISSN: 2222-6990 @ 2020 HRMARS

to the religious background of the respondents who were Christains. In Christainity, believers have to believe in destiny, or more accurately, divine destiny. This finding is in agreement with the Gray et al.'s (2006) findings which revealed that the prevailing thought among Cameroonian Entrepreneurs was that individuals should make their greatest effort to accomplish something, but that the result is subject to their destiny, which is related to what God has predicted for their lives. Conversely, the result of the present study does not support some other studies in different contexts (Miller et al., 2006; Alpkan et al., 2002) which found that internal locus of control was positively correlated with Entrepreneurial success.

\section{Propensity for Risk Taking}

Interesting findings were found about the propensity for risk taking. Although descriptive statistics revealed that Entrepreneurs of both successful and less successful firms tend to agree about the importance of taking risks in ensuring the success of their businesses, the inferential analysis, using Mann-Whitney $U$ test unfolded significant differences between the two groups. The finding suggests that the Entrepreneurs of successful Small businesses have higher propensity for risk-taking than their less successful counterparts. This finding shows similarity to several studies in different contexts. However, it is not consistent with the study of Siegel et al. (2003).

\section{Competences \& Skills of the Entrepreneur Managerial Competences}

Quantitative data analysis showed that managerial competences are crucial for the success of Entrepreneurs in Bamenda. Results of the descriptive analysis revealed that managerial competences were regarded as having great importance by Entrepreneurs of both successful and less successful firms. The finding of the study corroborates the finding of Koffi (2006) which revealed, based on a sample of 56 bankrupt enterprises in Cameroon; that $70 \%$ of failures were due to poor leadership and mismanagement. In addition, the finding is consistent with that of other studies in different contexts and supports the finding of Yusuf (2005) which revealed that good management skills are one of the factors most critical to the success of South Pacific islanders' Entrepreneurial activities. However, although managerial competences were considered to be very important, it was apparent that the magnitude of such importance varied for both groups. Results of the inferential MannWhitney $U$ test indicated that the perceived importance of managerial competences for the success of Entrepreneurs was stronger for Entrepreneurs of successful businesses than for their less successful counterparts. It should be noted here that the level of managerial competences could be linked to size of the firm which was discussed above. As argued by Greiner (1972), as firms grow, Entrepreneurs need to develop their leadership and management capabilities in response to the successive internal crises.

\section{Entrepreneurial Competences}

The quantitative phase of the study revealed that Entrepreneurial competences were considered to be important for the success of Entrepreneurs in Bamenda. Descriptive statistics indicated that Entrepreneurs of both successful and less successful businesses viewed Entrepreneurial competences as crucial for the success of their businesses. Specifically, a high importance was placed on the ability to scan the environment and identify customer needs. The results confirm Wang \& Ang's (2004) view that the ability to select high quality opportunities and devise appropriate strategies to turn these 
INTERNATIONAL JOURNAL OF ACADEMIC RESEARCH IN BUSINESS AND SOCIAL SCIENCES Vol. 10, No. 10, 2020, E-ISSN: 2222-6990 @ 2020 HRMARS

opportunities into reality may have a considerable impact on venture performance. Furthermore, results of the inferential analysis, using the Mann-Whitney $U$ test, showed no significant differences between Entrepreneurs of both successful and less successful Small businesses in Bamenda, in relation to the importance of Entrepreneurial competences. This suggests that both groups confirmed that Entrepreneurial competences are strong factors of business success.

\section{Functional Competences}

Findings of the quantitative phase of the study suggest that functional competences play an important role in the success of Entrepreneurs in Bamenda. Descriptive statistics indicated that Entrepreneurs of both successful and less successful businesses viewed functional competences as central to the success of their businesses. Specifically, a high importance was placed on the businessrelated competences. This conforms to the argument of Baum et al. (2001) who argued that technical or industry-related skills are an important source of "expert" power that legitimizes the Entrepreneur in the eyes of his/her staff, and assists in the implementation of the Entrepreneur's plan. In addition, findings of the quantitative phase are in line with the view of Barney (1991) who claims that it is essential for Entrepreneurs to acquire venture-specific skills to provide sustainable competitive advantage for their ventures.

The findings of the quantitative phase confirm that functional competences are strong factors of business success for Entrepreneurs of both successful and less successful Small businesses in Bamenda. However, significant differences on the importance of such competences existed between the two groups. Results of the inferential analysis, using the Mann-Whitney $U$ test, revealed that the perceived importance of functional competences to the success of Entrepreneurs was stronger for the Entrepreneurs of the successful businesses than for the less successful ones.

\section{Conclusion}

This study has shown that understanding the success of small businesses from the perspective of Entrepreneurs is a complex challenge. This complexity is not eliminated by the small size of the business but magnified, because of the personal nature of small firms. As argued by Simpson et al. (2012), success in business is a matter of opinion and may be related to the degree to which objectives are met or exceeded, some of which may be critical for success. The complexity is further illustrated when attempting to unravel the critical success factors (CSFs).

The quantitative phase found that age, education, experience, family background, need for achievement, risk-taking propensity, managerial competences, and functional competences of the small business manager were significantly related to success. These factors can be grouped under the category of entrepreneur attributes'. Every business needs skilled entrepreneurs that have a set of attributes, which are consistently mentioned in the literature relating to both developed and developing countries. Watson et al. (2000) reviewed previous research attempting to define clear characteristics shared by entrepreneurs which affect their success and concluded that "there is no simple pattern". They refer to the absence of a general theoretical framework and develop their own framework based on extant literature.

The findings deriving from this study regarding the interplay of factors that contribute to business success may be very important for practitioners, because they could provide Small business managers with an enhanced understanding of the ways in which they could manage the performance of their businesses. In broad terms, the study underlined the importance of skills and functional 
INTERNATIONAL JOURNAL OF ACADEMIC RESEARCH IN BUSINESS AND SOCIAL SCIENCES Vol. 10, No. 10, 2020, E-ISSN: 2222-6990 @ 2020 HRMARS

competences, which highlights the value of management training and development. More specifically, business and managerial skills were widely held to have a substantial impact on business success, especially in the Bamenda region, suggesting that entrepreneurs should see business and managerial skills development as an improvement priority.

\section{References}

Aidis, R., \& Mickiewicz, T. (2016). Small business managers, expectations and business expansion: lessons from Lithuania. Europe-Asia Studies, 58 (6), 855-880.

Aldrich, H. E., \& Reese, P. R. (2003). Does networking pay off? A panel study of small business managers in the research triangle. In N. Churchill, S. Birley, \& J. Doutriaux.

Babbie, E. R. (2016). The practice of social research (12 ed.). Belmont: Wadsworth, Cengage Learning.

Baum, J., \& Locke, E. A. (2015). The relationship of small business managerial traits, skill, and motivation to subsequent venture growth. Journal of Applied Psychology, 89 (4), 587-598.

Benzing, C., Chu, H. M., \& Kara, O. (2016). Small business managers in Turkey: A factor analysis of motivations, success factors, and problems. Journal of small business management, 47 (1), 58 91.

Bolton Committee Report. (1971). Report of the Commission of Inquiry on Small Firms. London: HMSO.

Child, J. (2003). Predicting and understanding organization structure. Administrative Science Quarterly, 18 (2), 168-185.

Emory, C. W., \& Cooper, D. R. (2011). Business research methods (4 ed.). New York: Irwin.

Man, T. W., \& Lau, T. (2014). The context of Business Innovation in Hong Kong: an investigation through the patterns of small business managerial competencies in contrasting Agribusiness environments. Journal of Small Business and Enterprise Development, 12 (4), 464-481.

Mazzaro , T., Volery, T., Doss, N., \& Thein, V. (1999). Factors influencing Small businessestart-ups. International Journal of Small business managerial Behaviour and Research, 5 (2), 48-130.

Nieman, G. (2016). Small business management: A South African approach. Van Schaik Publishers.

OECD, African Development Bank. (2009). African economic outlook 2009. Paris: African Development Bank.

Perez, E. H., \& Canino, R. M. (2009). The importance of the small business manager's perception of "success". Review of International Comparative Management, 10 (5), 990-1010.

Perez, S., Llopis, A., \& Llopis, J. (2004). The determinants of survival of Spanish Agribusiness firms. Review of Industrial Organisation, 25 (3), 251-273.

Polit, D. F., \& Hungler, B. P. (1999). Nursing research: Principles and methods (6th ed.). Philadelphia: Lippincott.

Sandberg, K. W. (2003). An exploratory study of women in micro enterprises: Gender-related differences. Journal of Small Business and Enterprise Development, 10 (4), 408-417.

Sapienza, H., \& Grimm, C. (2007). Founder characteristics, start-up process and strategy/structure variables as predictors of shortline railroad performance. Owner-managership Theory and Practice, 22 (1), 5-24.

Siegel, R., Siegel, E., \& MacMillan, I. C. (2003). Characteristics distinguishing high-growth ventures. Journal of Business Venturing, 8 (2), 169-180.

St Jean, E., Julien, P. -A., \& Audet, J. (2014). Factors associated with growth change in 'gazelles'. Journal of Enterprising Culture, 16 (2), 161-188. 
INTERNATIONAL JOURNAL OF ACADEMIC RESEARCH IN BUSINESS AND SOCIAL SCIENCES

Vol. 10, No. 10, 2020, E-ISSN: 2222-6990 @ 2020 HRMARS

Mbah, T. (2014). Contemporary business management, Green Edition. McDavid consulting group

Temtime, Z. T., \& Pansiri, J. (2004). Small business critical success/failure factors in developing economies: some evidences from Botswana. American Journal of Applied Sciences, 1 (1), 1825.

The Organisation for Economic Co-operation and Development. (2014). OECD Small business and Owner-managership outlook. Paris: OECD Publishing.

The World Bank. (2009). Doing Business 2009. Washington, DC: The World Bank.

The World Economic Forum, The International Bank for Reconstruction and Development/The World Bank, and The African Development Bank. (2009). The Africa competitiveness report 2009. Geneva: World Economic Forum.

Wang, C. K., \& Ang, B. L. (2004). Determinants of venture performance in Singapore. Journal of Small Business Management, 42 (2), 347-363.

Weinzimmer, L. G. (2003). A replication and extension of organizational growth determinants. Journal of Business Research, 48 (1), 35-41.

Woldie, A., Leighton, P., \& Adesua, A. (2016). Factors influencing Micro Enterprises (Small businesses): an exploratory study of owner/manager and firm characteristics. Banks and Bank Systems, 3 (3), 5-13.

Zikmund, W. G., Babin, B. J., Carr, J. C., \& Griffin, M. (2016). Business research methods (8th ed.). South-Western, Cengage Learning. 